Mozgovaya A. V.

\title{
METHODOLOGICAL POTENTIAL OF RESPONSIBILITY CONCEPT IN SOCIOLOGICAL PROVISION OF TECHNOLOGICAL RISK MANAGEMENT
}

$\mathrm{PhD}$, Head of risk problem and accident sector. Institute of Sociology, RAS. Krzhizhanovskogo str. 24/35, bld. 5, Moscow, 117218, Russia. E-mail: mozgovai@yandex.ru

\begin{abstract}
The article is devoted to the assessment of the responsibility concept methodological potential as the basis of scientific sociological substantiation of management decisions to minimize risks. The actualization of needs to risk analysis in a sociological approach relates by the author with the understanding that the explanation, prediction and risk management is not possible without taking into account the interests, values, attitudes, the lifestyle characteristics of individuals and social communities.

The proposition is introduced that the essence of risk management is in the substantiation the scope of its social acceptability sphere, andrisk communication is the control technology as a form of responsible relationships. Responsibility in the context of risk issues is considered in relation to such concepts as the attitudes, the value of life, living conditions, resources, subjects and responsibility adaptation and implementation strategies.

The data of sociological research in the territorial communities are presented where the core of conflict between the potential participants of risk communication are the technological risks and their acceptability. The interpretation of these studies confirms the thesis that the risk management in specific conditions shall be based not only on technological parameters, but also on sociological diagnosis data.

Keywords: responsibility; social acceptability of risk; risky communication; sociological support of management decisions.

\section{МЕТОДОЛОГИЧЕСКИЙ ПОТЕНЦИАЛ КОНЦЕПЦИИ ОТВЕТСТВЕННОСТИ В СОЦИОЛОГИЧЕСКОМ ОБЕСПЕЧЕНИИ} УПРАВЛЕНИЯ ТЕХНОЛОГИЧЕСКИМИ РИСКАМИ
\end{abstract}

\section{Мозговая A.B.}

кандидат философских наук, заведующая сектором проблем риска и катастроф. Институт социологии

РАН, ул. Кржижановского 24/35, к. 5, Москва, 117218, Россия. Электронный адрес: mozgovai@yandex.ru

\begin{abstract}
Аннотация. Статья посвящена оценке методологического потенциала концепции ответственности как основы научного социологического обоснования управленческих решений по минимизации рисков. Актуализация потребности в социологическом подходе к анализу риска соотносится автором с пониманием того, что объяснение, прогнозирование и управление рисками невозможно без учета интересов, ценностей, установок, особенностей жизненного уклада индивидов и социальных общностей.

Вводится положение о том, что сущность управления риском состоит в обосновании сферы его социальной приемлемости, а технологией управления является рисковая коммуникация как одна из форм ответственных отношений. Ответственность в контексте рисковой проблематики рассматривается в связи с такими понятиями как установки, ценность жизни, жизненные условия, ресурсы, субъекты и стратегии адаптации и реализации ответственности.

Приводятся данные социологических исследований в территориальных общностях, где ядром противоречий между потенциальными участниками рисковой коммуникации являются технологические риски и их приемлемость. Интерпретация данных исследований подтверждает тезис о том, что управление рисками в конкретных условиях должно
\end{abstract}


опираться не только на технологические показатели, но и на данные социологической диагностики.

Ключевые слова: ответственность; социальная приемлемость риска; рисковая коммуникация; социологическое обеспечение управленческих решений.

\section{Sociological approach to risk analysis}

The objectives of risk management by the majority of researchers and experts are formulated as an event occurrence probability reduction, an event that may lead to the destruction of material objects and population death, and the minimizing of damage in case of such an event implementation (the mitigation of consequences) [1]. The damage, however, is understood by the experts in various fields within the framework of those scientific disciplines, the basic concepts of which they share. A serious problem is that an «intangible» possible damage from a realized risk is acknowledged not by all experts and decision makers in the field of risk management.

Initially, the need for analysis, prediction and risk management was actualized in the economic sphere and was caused by the need of investment safety provision, life and property insurance.

The emergence of complex technological objects and the resulting anthropogenic hazard, implemented in the form of accidents and disasters (Seveso, Bhopal, Chernobyl, etc.), required enormous efforts and funds for the rehabilitation of territories and population, conditioned the development of socially oriented trends in the study of risk: cultural and psychological one (psychometric paradigm).

The need in a sociological approach to risk analysis was actualized together with the understanding of an obvious fact that the explanation and, therefore, the prediction and risk management is not possible without taking into account the interests, values, attitudes, characteristics of the way of life and a number of other components making a personality structure and a social experience of subjects, referred to in specific literature as risk producers and consumers [2].

The impetus for empirical risk studies was given by Charles Starr works in the late sixties of the last century [3]. He convincingly showed that the concepts of benefits / costs firmly established in the measurement of risk are not applicable on the level of individual actors and territorial communities acting in the situations of implemented accidents and risk disasters. Charles Starr introduced into the scientific circulation the notion of «voluntariness»" convincingly demonstrated at an empirical level that the assessment of the risk acceptability is not directly dependent on the amount of benefits. Further foreign and domestic studies, including more than twenty year personal experience of empirical research and expert activities in the areas of placement of objects with a potentially risky technological manufacturing in the areas of environmental disasters and catastrophes, have convincingly shown that such an assessment is performed not mathematically, but in a very different format.

For technical objects risk may be expressed numerically as the basic condition for an object stability is in the system rationality, the predictability of element functioning, including staff. The accidents at industrial facilities, that is, an implemented technological risk, have shown convincingly that the outcome is predictable roughly: the behavior of a facility personnel, experts involved in the process of destruction consequences minimization of the affected population can not be predicted clearly. The risk assessment is complicated manifold: it can't be quantified as it is carried out efficiently, often unknowingly using all the experience of of an individual socialization, shaped by the experience of internal personal and social attitudes.

The methodology, the methods, the techniques and the procedures of empirical sociology allow to identify the factors and conditions that correlate with the specifics of subjective and group attitudes that make up the positions of communities that are or may fall into specific conditions of technological risks. The perennial methodological and empirical research and developments in the field of risk sociology, the analysis of practices and strategies to risk adaptation allowed us to substantiate the conclusion that one of social inequality types is the inequality in the distribution of risks, the specificity of which consists in the differentiation of living conditions and the access to various resources required by subjects to adapt to risk. This fact is of great importance for the provision of risk management process efficiency, understood by us as the cooperation of all interested subjects in order to achieve an acceptable level of risk in a situation when it is impossible to achieve an absolute security.

This inequality, in its turn, stipulates the differences of starting positions and resources of 
such subjects as the risk producers and consumers in the process of adaptation and the achievement of a mutually acceptable level of risk. Socially acceptable risk, in its turn, as our research shows, depends on the interaction of individual and status estimates of an uncertain social situation, the probability of damage, the extent of vulnerability concerning natural and social environment objects and communities. Individual, group, status assessments of uncertainty, vulnerability, handling and other indicators characterizing a risk differ substantially among the representatives of various social subjects.

Sociology offers its view on the management within these conditions: the scope of risk acceptability shall be sought through the interaction of social actors, whose interests intersect in a risk situation: communities, the institutions of power, business, science, civil and social movements, mass media, etc. This search makes the essence of risk management, in its turn, risk communication acts as a tool, a mechanism, the social technology of control as a form of social communication [4]. A current and a complex problem is based on the following: the degree of result relevance concerning the humanitarian risk research on the part of business community and a power institution is extremely low. The results of research among psychologists and sociologists are difficult to imagine in the form of brief summaries, adopted in the technical sphere, prescribing the solutions in the form of nonvariant recommendations, as the technique is conditioned by a unique determination, as we noted above. Social problems are solved by the specific social administrative procedures between subjects, the procedures requiring qualitative sociological provision.

We used the methodological potential of sustainable development concepts, strategic risks and the quality of life since the studies of the Chernobyl disaster social consequences, during the development of recommendations on the basis of management decision sociological support. However, over time, the operation experience in the regions and territorial communities within the situations of technological risks or affected by manmade disasters showed that the most productive methodology of such sociological support is the concept of responsibility.

Liability issues in the context of the risk sociology issue.

In order to develop the sociological notions of responsibility as a methodological basis of empirical research we performed a comparative analysis of this notion definitions within the structure of various scientific discipline categories and the fields of social practices. Such key words as debt, obligations, dependency, rules, sanctions turned out to be similar in different definitions.

The assessment of the methodological value concerning various general sociological concepts led us to believe that the category of liability should be considered on the basis of the sociological notion concerning social control. We believe that the responsibility in the structure of sociological categories is a derivative of the social control function as the method of a system self-regulation, ensuring the orderly interaction of its constituent elements by standard (including legal one) regulation.

The subject of monitoring is a subject - object activity or subject - subject relations in a particular field of social life. The essence of responsibility as the derivative of the social control function is to ensure the performance of subject obligations institutionalized in law, social and moral standards, rules and traditions during the process of activities and relationships. The mechanism of responsibility implementation is in the sanctions for the breach of obligations, in a kind of dependence on them.

The features of perception and the attitudes of subjects, depending on the own and other subject responsibilities, a social and an individual experience on a personal level are formalized in the attitudes on an institutional level - in normative documents.

In the subject area of risk sociology a special interest is presented by activities and relationships, which are characterized by uncertainty, the potential for damage and subjectively experienced vulnerability. An empirical sociology, in particular the sociology of risk is interested in factors, on the basis of which the decision for a specific action is taken under or against the standards and duties prescribed by social control and as a consequence the risk of failure (adverse effects) during the process of adaptation and the achievement of an acceptable risk level.

Responsibility in the context of the risk perspective, as the analysis of our research and expertise, research, the fellows of «humanitarian research workshop» shows, is appropriate to consider in relation to such concepts as the attitudes, the value of life, living conditions, resources, subjects and adaptation strategies and responsibility implementation.

One of the major challenges is the identification of factors correlated with the perception of and the 
attitude to social the responsibility of social actors involved (voluntarily or involuntarily) in the communications concerning the management of technological risks. The most common situation is the situation that we identified as ecological and economic controversy one time [4], the essence of which is in the contradiction of interests concerning the conservation of the environment and public health on the territory of potentially hazardous industry placement and the economic interests of certain persons, including the representatives of local communities.

The abovestated perception and attitude towards liability have an attitude in its basis, understood as the value attitude to this or that social object. The attitude requires primarily an empirical interpretation. In the most general sense in relation to a risk and responsibility the attitudes may be classified according to responsibility taking criteria, that is, a full and a strict compliance with the obligations; the transfer (concession, alienation) of liability in favor of other activity and relationship subject; a partial or a complete refusal from the performance of duties. The acceptance and the transfer of responsibility is characterized by security in relation to sanctions; a refusal is a risk decision, the consequences of which could be the use of different kinds of sanctions.

An attitude, in particular a social attitude as a value relation to a particular object (including a social object) is the product of life experience and is developed in the process of socialization, which in its turn depends on the interest and the activity of a person. The wider the range of interests and the higher activity is, the more successful the process of socialization is and the more comfortable the feeling of an individual in a social environment.

The acquisition of social and cultural experiences, materialized in the patterns of behavior, social norms and values occurs in the communication process at different structural levels of a social environment: in a family, in educational institutions, in the work teams, in different reference groups according to the degree of proximity (friends, neighbors, partners for leisure activities, civic engagement, etc.)

For the purposes of our analysis, it is important that the transformation of sanction nature, the replacement of the external individual sanctions imposed by the social environment on the internal self-regulation, self-control in the form of certain attitudes take place in the process of socialization. The most difficult part in the sociological study is to measure an attribute interesting for a researcher. As you know the main method of an attitude measurement is scaling (Likert, Thurstone, Guttman scale). In order to measure a specific attitude, the factors correlated with its properties and the structural elements its «decomposition» is required in concepts (operationalization) and indicators (empirical interpretation). The process, of course, is a subjective one, but a practicing sociologist does not have any other way from it.

Thus, we need to «spread out» the following concepts: responsibility, the attitude towards responsibility in a certain situation, the specificity of a situation, social subjects - the participants of a situation, the factors correlating with the properties of an attitude.

It is not possible to measure such a structural component of an attitude as an emotional one, it is extremely difficult to measure a conative (behavioral) component, it is possible to measure the cognitive component of an attitude actually with some degree of certainty. The attitude properties that are known for researchers may be measured now by a survey: availability, stability, intensity, direction, modality (whether this attitude is necessary, possible or accidental one). The determination of an attitude type interesting for a researcher seems to be possible: according to a place the system of values (base / peripheral one), according to functions (instrumental, cognitive and protective one).

General sociological arguments about the responsibility is vividly illustrated by the example of such a social subject as a large holding during the implementation phase on the territory of accommodation with the profile far from the specificity of the holding company, not differing by technological risks. The specifics of the situation is precisely distinguished by the contradictions between the interests of natural environment maintaining and the economic benefits from the introduction of a new large-scale industrial production. The core of the controversy are the risks the acceptability of which is estimated differently by the parties and may be found, as noted above, only in the communication process, called risk communication in the specific literature. The participants of communication (conflict parties) are presented (voluntarily or involuntarily) by the community («placement area» according to RSPP terminology), the company, the mass media, the neutrality of which is implied.

Local community is represented by social organizations, civil movements, initiative groups, etc. as an active part of the population, local authorities, the passive part of the population. The 
company is represented by the shareholders, as the residents of the local community and foreign ones in respect to the site of the company placement, the employees of various levels (from managers to workers), «lobbyists» promoting the interests of the company for one reason or another, not being its shareholders or employees. The mass media, participating in the process of risk communication should provide equal information opportunities to present the interests of the parties.

The sociological provision of the risk management process in this situation requires the identification and the analysis of various categories of population attitude specifics as one of the environmental and economic contradiction subjects concerning the responsibility of a particular type, namely - a responsible attitude towards the environment, and also the social factors that correlate with it. Operationalization is performed for two basic concepts at least: an attitude towards responsibility concerning the environment and the factors that characterize the specificity of the socialization process during which this attitude was developed (socialization experience).

The data from one of our studies in the communities which are directly in the situations of environmental and economic contradictions, revealed in particular the following specifics. The non-economic factors shaping the behavior of the population have the significance as important as the material factors during the formation and the reproduction of worldviews, influencing in particular the attitude to one's own responsible behavior and responsibility expectations from other participants of interpersonal and social relations. These non-economic factors are represented by trust, control and adaptation. Trust meets the expectations of a responsible behavior - the performance of obligations by individuals and social institutions; control reflects the level of impact on the implementation of social subject obligations; adaptation shows the degree of socialization and the level of involvement in social interaction. The level of control and adaptation may be considered as derivatives from the confidence indicator to social interaction participants.

In particular, a number of studies showed the following. The population control as an indicator of the impact level on the implementation of the duties by social actors in relation to health and the environment protection is extremely low. The awareness of legal rights for a healthy environment and the participation in the protection of their rights is weak, the appeal to corresponding authorities on issues of environmental protection from the harmful influence of enterprises is low and the feedback is almost a zero one.

The interest in the information about the environment state is high and the level of awareness is low, the confidence in the sources is low. Trust as an indicator of obligation performance expectations by social institutions in the field of public health and environment protection is extremely low; the assessments concerning the levels of social actor interest in environmental protection are also extremely low.

There is a social situation, the essence of which is that the social partnership of population, the representatives of authorities and businesses concerning environmental protection issues exist only as a declaration. Population is mainly passive, it does not take the responsibility for the preservation of the environment and transfers it to other social actors - the business community, governmental structures and in fact it does not participate at all and at that demonstrates high demands on social security. Obviously, a developer with such data may develop a more reasonable management decisions than the one who does not have such data.

Another example from our practice of studying the factors associated with the formation of the population trust attitudes and the implementation of control as the attributive characteristics of responsible cooperation within the territorial community, which is in the situation of an acute, imposed risk. A special sociological procedure allowed to carry out the typology of respondents concerning an attitude focus on the evaluation of the power institute and large business responsibility concerning the protection of the environment and public health. The analysis revealed within a territorial community some stable groups of respondents who positively or, on the contrary, negatively evaluate the actions of authorities and large business as a social entity (a generalized attitude) and a particular company, whose work with the new risks is «imposed» to the community (a situational attitude). Another target group of respondents was formed additionally who had common focused and generalized situational attitude - these are the «consecutive» respondents who equally (positively or negatively) assess the responsibility of authorities in general, and a specific situation in particular where a territorial community appeared according to the decision of authorities. The results of comparative analysis show convincingly that the focus of attitudes is correlated with the differentiation of respondents across a whole range of social indicators. Scientifically substantiated 
management influence on these social indicators may be adjusted over time and the orientation of the respondents' attitudes regarding the responsibility estimates of social actors specified above.

These examples confirm our repeatedly expressed thesis that social management and risk management in specific circumstances should be based not only on technological parameters, but also on the data of sociological diagnosis, not on public opinion surveys, namely on well-conducted sociological research, considered as a scientific basis for administrative decisions [5].

\section{References:}

1. Strategic risks of Russia: estimation and forecast / MES of Russia; Chief editor Y.L. Vorobyov. M.: Business Express, 2005. 392 p.

2. Yanitsky O.N. Sociology of risk. M.: Publishing House LVS, 2003.

3. Starr Ch. Social Benefit versus Technological Risk // Science. 1969. Vol. 165. No. 3899 (September). P. 1232-1238.

4. Mozgovaya A.V., Komarov V.A. Sociological provision of risk communication // Risk: sociological analysis, communication, regional management / Chief editor A.V. Mozgovaya M.: Publishing House of the Institute of Sociology, 2004. pp. 143-156.

5. Risk: studies and social practice. M.: Institute of sociology RAS, 2011. 256 p. 